УДК 338.4./330.1

Бутко Б. О.,

bobbybagdad@gmail.com, ORCID0000-0002-9769-7523,

здобувач, Львівський торговельно-економічний університет, м. Львів

\title{
СУТНІСНА ХАРАКТЕРИСТИКА КРИТЕРІЇВ ПІДВИЩЕННЯ ЕФЕКТИВНОСТІ КОМЕРЦІАЛІЗАЦІЇ ВИСОКОТЕХНОЛОГІЧНОЇ ПРОДУКЦІї
}

\begin{abstract}
Анотація. У статті розкрита сутнісна характеристика критеріїв підвищення ефективності інструментів комериіалізації високотехнологічної продукції та визначено багатокритеріальний підхід до оцінки ефективності даних інструментів. Розроблено горизонтальну класифікацію критеріїв підвищення ефективності комериіалізації за функціональними аспектами діяльності підприємств, здійснено змістовний виклад та тлумачення даних критеріїв, запропоновано систему кількісних показників ефективності діяльності, відповідних кожному з критеріїв. Метою дослідження є визначення оптимальних критеріїв оцінки ефективності комериіалізації в горизонтальному, функиіональному аспекті високотехнологічного сектору з урахуванням неринкового середовища, формування багатокритеріального портфоліо аналізу иьього ринку для подальшого створення відповідної багатофакторної моделі. Незважаючи на сучасні вітчизняні розробки, визначення найбільш оптимальних критеріїв оцінки ефективності комерціалізації високотехнологічних продуктів залишається перспективним завданням. Слід зазначити, щзо певні сфери бізнесу, пов'язані із потребами споживачів та неринковим середовищем, а саме маркетинг, імідж, інтеграція та екологія довгий час залишались поза увагою вітчизняних дослідників. Загалом, враховуючи запропоновані методологічні підходи до очінки ефективності високотехнологічної комериіалізації, слід зазначити, щзо подальший розвиток багатокритеріального підходу до вдосконалення комериіалізації високотехнологічного продукту та технології полягає у створенні відповідної моделі, заснованої на поєднанні якісних та кількісних методів ефективності. Визначено дев'ять критерїв оцінки ефективності, а саме: економічний, технологічний, фінансовий, маркетинговий, ресурсний, соціальний, екологічний, іміджевий, інтеграційний, котрі є чітким відображенням набору конкретних взаємозв'язків у галузі високотехнологічних продуктів у кількісному та якісному вираженні та є достатньою умовою для подальшого моделювання як складової стратегї комериіалізації високотехнологічного продукту.
\end{abstract}

Ключові слова: комерціалізація, високотехнологічна продукція, високі технології, економічні критерії ефективності, кількісні показники, стратегія, інвестиційний процес, інновації.

Butko B. O., bobbybagdad@gmail.com,ORCID 0000-0002-9769-7523, Postgraduate, Lviv University of Trade and Economics, Lviv

\section{ESSENTIAL CHARACTERISTIC OF CRITERIA FOR INCREASING THE EFFICIENCY OF HIGH-TECH PRODUCTS COMMERCIALIZATION}

\footnotetext{
Abstract. The article reveals the essential characteristics of the criteria for improving the efficiency of tools for commercialization of high-tech products and identifies a multi-criteria approach to assessing the effectiveness of these tools. The horizontal classification of criteria of efficiency increase of commercialization on functional aspects of activity of the enterprises is developed as well as the meaningful presentation and interpretation of these criteria proposed. A system of quantitative performance indicators corresponding to each of the criteria is proposed. The aim of the study is to determine the optimal criteria for assessing the effectiveness of commercialization in the horizontal, functional aspect of the high-tech sector, taking into account the non-market environment, forming a multicriteria portfolio of analysis of this market to further create an appropriate multifactor model. Despite current domestic developments, determining the most optimal criteria for assessing the effectiveness of commercialization of high-tech products remains a promising task. It should be noted that certain areas of business related to consumer needs and non-market environment, namely marketing, image, integration and ecology for a long time remained out of the attention of domestic researchers. All-in-all, the proposed methodological approaches to assessing the effectiveness of high-tech commercialization, it should be noted that the further development of a multi-criteria approach to improving
} 
the commercialization of high-tech product and technology is to create an appropriate model based on a combination of qualitative and quantitative methods of efficiency. Nine identified criteria for assessing efficiency, namely: economic, technological, financial, marketing, resource, social, environmental, image, integration is a clear reflection of a set of specific relationships in the field of high-tech products in quantitative and qualitative terms, is a sufficient condition for further modeling as component of the strategy of commercialization of high-tech product.

Key words: commercialization, high-tech products, high technologies, economic efficiency criteria, quantitative indicators, strategy, investment process, innovations.

\section{JEL Classification: M21, O32, P47 \\ DOI: https://doi.org/10.36477/2522-1205-2020-61-21}

Постановка проблеми. Комерціалізація високотехнологічного продукту та технології є ключовим практичним орієнтиром стимулювання поступу інноваційного процесу та формування національної інноваційної системи України. Головним завданням реалізації успішної комерціалізації на мікрорівні $€$ формування цільової стратегії окремого підприємства високотехнологічного сектору та її ключових компонентів, зокрема моделі підвищення ефективності інструментів комерціалізації, що, в свою чергу, потребує попередніх напрацювань. Актуальність дослідження полягає у невідкладності пошуку дієвих, зрозумілих та компактних економічних рішень для якомога менш проблемного виведення вітчизняних підприємств на орбіту відповідної загальновизнаним стандартам конкурентоспроможності у системі міжнародного підприємництва.

Аналіз останніх досліджень і публікацій. Визначенням та критичним аналізом засадничих критеріїв оцінки ефективності комерціалізації високотехнологічної продукції та технологій займалися Н. В. Бичкова [1], А. Ю. Данілкова [6], Й. А. Даньків [7], А. В. Карпенко [3], О. С. Літвінов [4], М. І. Маниліч [2], Т. В. Полозова [5] та ін.

Незважаючи на поточні вітчизняні напрацювання, визначення найбільш оптимальних критеріїв оцінки ефективності комерціалізації високотехнологічної продукції залишається наразі перспективним завданням. Окремо слід зазначити, що окремі напрямки діяльності підприємств, що пов'язані 3 потребами споживачів та неринковим середовищем, а саме: маркетинговий, іміджевий, інтеграційний та екологічний, - тривалий час залишаються поза увагою вітчизняних дослідників.

Постановка завдання. Визначити оптимальні критерії оцінки ефективності комерціалізації у горизонтальному (тобто функціональному) аспекті діяльності підприємств високотехнологічного сектору з урахуванням неринкового середовища, формування багатокритеріального портфеля аналізу явищ цього ринку з метою створення відповідної багатофакторної моделі.

Виклад основного матеріалу дослідження. Специфіка природи ринку високотехнологічної продукції та технології у вимірі сучасної проблематики економічної системи вимагає застосування усвідомлення фундаментальних засад та характерних їм специфічних підходів до оцінки ефективності інструментарію комерціалізації високотехнологічного продукту в системі міжнародного підприємництва та при формуванні міжнародної конкурентоспроможності в межах цієї системи.

Вирішення цих задач полягає у розробці дієвої моделі підвищення ефективності інструментів комерціалізації, що є можливою за умови визначення інтегральних критеріїв, що охоплюють всю сукупність економічних відносин 3 приводу утворення високотехнологічного продукту та технології, та подальшого викладу класифікацій та відповідних їм кількісних показників ефективності.

Горизонтальна класифікація інструментів ефективності має функціональний характер і відображає критерії ефективності діяльності суб'єктів ринку високотехнологічної продукції з урахуванням неринкового компонента (табл. 1).

До субкритеріїв економічного критерію ефективності варто віднести: відсоток прибутку від продажу ліцензій у загальній структурі отриманих прибутків; відсоток прибутку від інжинірингових та технологічних послуг у загальній структурі отриманих прибутків; вплив НДДКР на підвищення продуктивності виробництва в результаті комерціалізації; зниження обсягів необхідних інвестицій в основний капітал завдяки НДДКР; зниження собівартості продукції при незмінній або покращеній його якості завдяки запровадженню високих технологій; збільшення обсягів виробництва, економія ресурсів завдяки ресурсозберігаючим високим технологіям; зміни у вартості нематеріальних активів підприємства.

Загальновживаними субкритеріями фінансового критерію комерціалізації є: операційний прибуток (EBITDA), чистий прибуток, чистий приведений (дисконтований) дохід (NPV), індекс дохідності (ІД), розрахунок доданої вартості (EVA), рентабельність результатів комерціалізації, індекс (коефіцієнт) рентабельності та інші. Розрахувати економічний ефект від інвестування можна шляхом визначення сумарного економічного ефекту від реалізації проектів 3 енергозбереження, а саме: зменшення витрат на оплату усіх ресурсів у результаті використання енергозберігаючих технологій та обладнання, а також результатів проведення внутрішнього аудиту енергетичною службою підприємства; зменшення витрат на оплату праці 
(шляхом автоматизації виробничих процесів); зменшення інших витрат, наприклад податків (екологічний податок); припинення нарахувань штрафних санкцій; дохід підприємств від продажу нової продукції з низькою енергомісткістю [6].

До субкритеріїв науково-технологічного критерію можна віднести: коефіцієнт механізації; коефіцієнт автоматизації; питому вагу передових технологічних процесів; коефіцієнт капіталоозброєності виробництва; питому вагу продукції, виготовленої прогресивними технологічними методами; питому вагу робіт, виконаних за прогресивною технологією; питому вагу машинного часу в технологічній трудомісткості; коефіцієнти уніфікації та стандартизації.

Маркетинговий критерій ефективності виражається у наступних субкритеріях: частка ринку нової продукції; розширення частки ринку; відсоток розширення номенклатури та асортименту продукції; відсоток нової випущеної продукції у структурі виробництва; частки продажу інноваційної продукції у структурі обсягів продажу та інші. На основі аналізу функцій міжнародного маркетингу до субкритеріїв маркетингового критерію також відносять наступні показники: ємність ринку; коефіцієнт невизначеності; динаміка міжнародної конкурентоспроможності підприємства; коефіцієнт підприємницького ризику; приріст обсягів продажу на зарубіжних ринках; динаміка міжнародної конкурентоспроможності продукту; динаміка коливання цін; скорочення терміну окупності інвестицій у міжнародний маркетинг; динаміка збуту за ринками; витрати на просування та стимулювання про- дукту; витрати на рекламу та PR-заходи; динаміка лояльності споживачів тощо.

Соціальний критерій включає: кількість нової та удосконаленої продукції на ринку; підвищення якості життя споживачів; зростання доходів населення; кількість нових робочих місць; зниження цін нової продукції; підвищення ефективності управління; покращення умов праці; зростання мотивації працівників підприємств; всебічний розвиток здібностей людини тощо.

Необхідність досягнення високого рівня екологічного критерію націлює компанії на створення більшої споживчої цінності для споживачів при мінімізації використання природних ресурсів, забруднення навколишнього середовища і продукування відходів. В основі такого цілепокладання лежить акцент на створенні продукції з високими споживчими властивостями, низькою матеріаломісткістю та енергоємністю виробництва. Тому субкритеріями екологічного критерію можуть бути як абсолютні, так і відносні показники: обсяг інвестицій у екологічні проекти; окупність таких проектів; рівень економії ресурсів, досягнутий від зменшення (технологічної заміни) використання сировини; впровадження запобіжних заходів чи вторинного використання сировини; кількість матеріалів та енергії, що використовуються на одиницю продукції; кількість енергії, зекономленої внаслідок впровадження програми 3 енергозбереження на одиницю продукції; кількість небезпечних речовин (компонентів) на одиницю продукції; кількість і тип відходів, які виникають внаслідок реалізації проекту комерціалізації; кількість специфічних викидів на одиницю продукції.

Таблиия 1

Виміри (критерії) ефективності комерціалізації високотехнологічного продукту

\begin{tabular}{|l|l|}
\hline \multicolumn{1}{|c|}{ Вимір (критерій) } & \multicolumn{1}{c|}{ Особливості критеріїв } \\
\hline 1. Економічний & $\begin{array}{l}\text { Враховують (переважно у вартісному вираженні) всі види результатів і витрат, } \\
\text { обумовлених співробітництвом у сфері високих технологій }\end{array}$ \\
\hline 2. Науково-технічний & $\begin{array}{l}\text { Відображають стан та динаміку науково-технічного потенціалу підприємства, } \\
\text { галузі, країни, глобального економічного ринку }\end{array}$ \\
\hline 3. Фінансовий & $\begin{array}{l}\text { Відображають величину грошових потоків при комерціалізації високотехноло- } \\
\text { гічного продукту, фінансову стійкість, надійність, ліквідність та беззбитковість } \\
\text { реалізації інноваційних проектів }\end{array}$ \\
\hline 4. Маркетинговий & $\begin{array}{l}\text { Базуються на моніторингу динаміки сегмента ринку високих технологій, зумо- } \\
\text { влюють можливість реалізації комерційно успішного співробітництва як у на- } \\
\text { ціональному, так і міжнародному аспектах }\end{array}$ \\
\hline 5. Ресурсний & $\begin{array}{l}\text { Відображають вплив новоствореного та/або удосконаленого високотехнологіч- } \\
\text { ного продукту на ефективність та масштаби виробництва і споживання того чи } \\
\text { іншого виду ресурсу підприємств }\end{array}$ \\
\hline 6. Соціальний & $\begin{array}{l}\text { Враховують соціальні наслідки реалізації комерціалізації проектів у сфері висо- } \\
\text { ких технологій }\end{array}$ \\
\hline 7. Екологічний & $\begin{array}{l}\text { Відображають наслідки прямого чи опосередкованого впливу комерціалізації } \\
\text { високотехнологічного продукту на стан навколишнього середовища та його } \\
\text { зворотний вплив на процес виготовлення інноваційного продукту }\end{array}$ \\
\hline 8. Інтеграційний & $\begin{array}{l}\text { Відображають рівень інтегрованості суб'єктів вітчизняної ринкової взаємодії } \\
\text { при створенні високотехнологічного продукту у світове господарство }\end{array}$ \\
\hline 9. Іміджевий & $\begin{array}{l}\text { Характеризують ступінь досягнення вітчизняним підприємством чи національ- } \\
\text { ною інноваційною системою статусу лідера у галузі високих технологій }\end{array}$ \\
\hline
\end{tabular}

Джерело: побудовано на основі [1-5]. 
На даному етапі міжнародне співтовариство розглядає показники стану навколишнього середовища як комплексний інструментарій для виміру і репрезентації еколого-економічних тенденцій у тій чи іншій країні. Відповідно, можна виділити три основні типи показників, які можуть бути використані в якості комплексних субкритеріїв екологічного критерію ефективності міжнародного співробітництва у сфері високих технологій:

- показники сучасного екологічного стану, що визначають діючі екологічні параметри;

- показники впливу чи тиску, що відображають антропогенний характер впливу на навколишнє середовище;

- показники, що регулюють вплив на навколишнє середовище i за допомогою яких можна визначити, як різні агенти реагують на специфічний вплив.

До субкритеріїв інтеграційного критерію ефективності відносять: частку експорту та імпорту у загальному обсязі продукції, виготовленої ринковим суб'єктом; частку прямих іноземних інвестицій у загальному обсязі капіталовкладень тощо.

До субкритеріїв іміджевого критерію можна віднести: розрахунок ефективності рекламних та PR-компаній; зміни у сприйнятті продуктів підприємства: споживачами, працівниками, акціонерами та суспільством загалом; збільшення кількості лояльних клієнтів до продукції підприємства; зміни в усвідомленні цінності компанії споживачами; коефіцієнт підвищення іміджу компанії; кількість згадувань компанії у ЗМІ тощо.

Багатокритеріальний підхід передбачає оцінку ефективності на підставі побудови стратегії підприємства. При цьому ефективність діяльності оцінюється як фінансовими, так і нефінансовими показниками, кількість яких обмежена, та відображаються причинно-наслідкові зв'язки між стратегією й операційною діяльністю, між цілями і результатами. При цьому слід розрізняти загальні показники ефективності, що характеризують ефективність діяльності підприємства в цілому (при розрахунку загальних показників враховуються весь сукупний результат і всі сукупні витрати (ресурси) підприємства) і часткові показники ефективності, що характеризують рівень використання окремих видів ресурсів і коштів (при розрахунку окремих показників враховуються результати і витрати (ресурси), що відповідають об'єкту розрахунку ефективності) [7].

Цей підхід дозволяє зробити найбільш вдалий вибір рішення в умовах невизначеності (відсутність точних і об'єктивних даних), а також при співставленні критеріїв різної природи. Наприклад, необхідно в даний момент прийняти рішення, в який напрямок сфери високих технологій слід більше інвестувати на міжнародному ринку: у прикладний розвиток тонкої хімії, у нанотехнології, інформаційно-комунікаційні чи біотехнології тощо [8-10].

Висновки і перспективи подальших досліджень у даному напрямі. Підсумовуючи виклад запропонованих методологічних підходів до оцінки ефективності комерціалізації високих технологій, слід зазначити, що подальший розвиток визначеного багатокритеріального підходу підвищення ефективності комерціалізації високотехнологічного продукту та технології полягає у створенні відповідної моделі, що базується на поєднанні якісних та вищевикладених кількісних методів оцінки ефективності. Визначені 9 критеріїв оцінки ефективності, а саме: економічний, технологічний, фінансовий, маркетинговий, ресурсний, соціальний, екологічний, іміджевий, інтеграційний - $є$ наочним відображенням сукупності специфічних взаємовідносин у сфері високотехнологічної продукції у кількісному та якісному вимірах, є достатньою умовою для подальшого формування моделі як складової елементу стратегії комерціалізації високотехнологічного продукту.

\section{ЛІТЕРАТУРА}

1. Бичкова Н. В. Детермінанти ефективності фінансової діяльності ТНК в умовах глобальних економічних трансформацій / Бичкова Н. В., Коновалова А. А. // Вісник Одеського національного університету. Серія: Економіка. - Одеса, 2013. Т. 18, Вип. 4(1). - С. 21-25.

2. Маниліч М. І. Система показників комплексної оцінки ефективності регулювання трансферу технологій / Маниліч М. І., Лихолет С. І. // Збірник наукових праць Буковинського університету. Економічні науки. - Чернівці, 2013. - Вип. 9. - С. 5-25.

3. Карпенко А. В. Теоретико-методичні основи оцінювання результативності наукової діяльності в Україні / Карпенко А. В., Будицька Ю. О. // Наукові праці Кіровоградського національного технічного університету. Економічні науки. - Кіровоград, 2017. - Вип. 31. - С. 51-57.

4. Літвінов О. С. Визначення сутності та складових організаційно-економічного механізму управління підприємством в умовах інноваційного розвитку / Літвінов О. С., Капталан С. М. // Управління розвитком. - 2016. - Вип. 3. - С. 59-65.

5. Полозова Т. В. Організаційно-економічний механізм управління інноваційно-інвестиційною спроможністю підприємства / Полозова Т. В. // Науковий вісник Міжнародного гуманітарного університету. Серія: Економіка і менеджмент. Одеса, 2017. - Вип. 23. Ч. 1. - С. 126-131.

6. Данілкова А. Ю. Аналіз системи показників ефективності залучення фінансових ресурсів при реалізації енергоефективної політики на промислових підприємствах / Данілкова А. Ю. // Економічні науки. - 2015. - № 12 (45). Ч. 1. - С. 102-109.

7. Даньків Й. Я. Ефективність діяльності підприємства: аналітичні аспекти / Даньків Й. Я., Макарович В. К. // Бухгалтерський облік і аудит. - 2017. - № 6. - С. 30-40.

8. Бритько А. С. Многокритериальный подход к оценке эффективности проектов инновационного развития высокотехнологичных предприятий : автореф. дисс. на соискание ученой степени канд. эконом. наук: спец. 08.00.05. - Санкт-Петербург, 2015. - C. 165. 
9. Ивасенко А. Г. Инновационный менеджмент: научное издание / Ивасенко А. Г., Никонова Я. И., Сизова А. О. - М. : КНОРУС, 2009. - 416 с.

10. Марамохина Е. В. Использование принципов теории многокритериального выбора при оценке эффективности экономических систем / Марамохина Е. В., Юрлов Ф. Ф. // Молодой ученый. 2014. - № 11 (70). - С. 216-220.

\section{REFERENCES}

1. Bychkova, N. V. and Konovalova, A. A. (2013), Determinanty efektyvnosti finansovoi diial'nosti TNK v umovakh hlobal'nykh ekonomichnykh transformatsij, Visnyk Odes'koho natsional'noho universytetu. Seriia: Ekonomika., Odesa, T. 18, vyp. 4(1), s. 21-25.

2. Manylich, M. I. and Lykholet, S. I. (2013), Systema pokaznykiv kompleksnoi otsinky efektyvnosti rehuliuvannia transferu tekhnolohij, Zbirnyk naukovykh prats' Bukovyns'koho universytetu. Ekonomichni nauky., Chernivtsi, vyp. 9, s. 5-25.

3. Karpenko, A. V. and Budyts'ka, Yu. O. (2017), Teoretyko-metodychni osnovy otsiniuvannia rezul'tatyvnosti naukovoi diial'nosti v Ukraini, Naukovi pratsi Kirovohrads'koho natsional'noho tekhnichnoho universytetu. Ekonomichni nauky., Kirovohrad, vyp. 31, s. 51-57.

4. Litvinov, O. S. and Kaptalan, S. M. (2016), Vyznachennia sutnosti ta skladovykh orhanizatsijnoekonomichnoho mekhanizmu upravlinnia pidpryiemstvom v umovakh innovatsijnoho rozvytku, Upravlinnia rozvytkom, vyp. 3, s. 59-65.
5. Polozova, T. V. (2017), Orhanizatsijnoekonomichnyj mekhanizm upravlinnia innovatsijnoinvestytsijnoiu spromozhnistiu pidpryiemstva, Naukovyj visnyk Mizhnarodnoho humanitarnoho universytetu. Seriia: Ekonomika i menedzhment, Odesa, Vyp. 23. Ch. 1., s. 126-131.

6. Danilkova, A. Yu. (2015), Analiz systemy pokaznykiv efektyvnosti zaluchennia finansovykh resursiv pry realizatsii enerhoefektyvnoi polityky na promyslovykh pidpryiemstvakh, Ekonomichni nauky, № 12 (45), Ch. 1, s. 102-109.

7. Dan'kiv, J. Ya. and Makarovych, V. K. (2017), Efektyvnist' diial'nosti pidpryiemstva: analitychni aspekty, Bukhhalters'kyj oblik $i$ audyt, № 6, s. 30-40.

8. Bryt'ko, A. S. (2015), Mnohokryteryal'nyj podkhod $\mathrm{k}$ otsenke effektyvnosty proektov ynnovatsyonnoho razvytyia vysokotekhnolohychnykh predpryiatyj : avtoref. dyss. na soyskanye uchenoj stepeny kand. ekonom. nauk: spets. 08.00.05., SanktPeterburh, s. 165.

9. Yvasenko, A. H. Nykonova, Ya. Y. and Syzova, A. O. (2009), Ynnovatsyonnyj menedzhment: nauchnoe yzdanye, KNORUS, M., $416 \mathrm{~s}$.

10. Maramokhyna, E. V. and Yurlov, F. F. (2014), Yspol'zovanye pryntsypov teoryy mnohokryteryal'noho vybora pry otsenke effektyvnosty ekonomycheskykh system, Molodoj uchenyj, № 11 (70), s. 216-220.

Стаття надійшла до редакції 19 жовтня 2020 p 